The Canadian Mineralogist

Vol. 43, pp. 1745-1758 (2005)

\title{
ANOMALOUSLY HIGH $\delta$ D VALUES IN AN ARCHEAN FERROPICRITIC MELT: IMPLICATIONS FOR MAGMA DEGASSING
}

\author{
WILLIAM EDWARD STONE ${ }^{\S}$ \\ Nevada Star Resource Corporation, 1400, 355 Burrard Street, Vancouver, British Columbia V6C 2G8, Canada \\ ETIENNE DELOULE \\ Centre de Recherches Pétrographiques et Géochimiques - Centre National de la Recherches Scientifique, \\ BP20, F-54501 Vandoeuvre-lès-Nancy Cedex, France \\ STEPHEN W. BERESFORD \\ School of Geosciences, Monash University, Clayton, Victoria 3800, Australia \\ MARCO FIORENTINI \\ School of Earth and Geographical Sciences, University of Western Australia, Crawley, WA 6009, Australia
}

\begin{abstract}
In situ $\mathrm{H}$ isotope analysis of igneous amphibole from the Boston Creek ferropicrite, in the Abitibi Belt, Ontario, a 100-m-thick layered mafic-ultramafic unit, provides insights into the evolution of Archean mantle-derived hydrous melts in the crust. Ionmicroprobe analyses of the ultramafic-rock-hosted interstitial igneous magnesiohastingsite indicate a wide range of $\delta \mathrm{D}$ values, from -47 to $+54 \%$ and $2-3 \mathrm{wt} \% \mathrm{H}_{2} \mathrm{O}$ at the $100-1000 \mu \mathrm{m}$ intragrain scale, but relatively uniform major-element and incompatible trace-element compositions. This wide range encompasses values significantly higher than the $\delta \mathrm{D}$ values of $-50 \%$ for whole-rock samples, $<+10 \%$ for igneous amphiboles from ultramafic sills, -80 to $-30 \%$ values for hydrothermal-metamorphic fluids in the area, and -90 to $-60 \%$ values for mantle materials. The anomalously high $\delta \mathrm{D}$ values cannot be attributed entirely to $\mathrm{H}$ loss from amphibole during secondary processes. The contrast with the relatively uniform magnesiohastingsite composition and $\mathrm{H}_{2} \mathrm{O}$ and trace-element contents of the amphibole excludes the possibility that the $\delta \mathrm{D}$ values reflect variable fluid/mineral fractionation. The anomalously high $\delta \mathrm{D}$ values most plausibly record the composition of the ferropicritic melt from which the amphibole formed. Considering the widespread distribution and abundance of vesicles in the Boston Creek ferropicrite, these values can be explained by degassing of $\mathrm{H}$ relative to deuterium, perhaps by dissociation of $\mathrm{H}_{2} \mathrm{O}$ during emplacement at shallow levels in the crust. The resulting increase in oxidation state of the residual degassed melt led to $\mathrm{Fe}-\mathrm{Ti}$ oxide crystallization, which reduced the $\mathrm{FeO}$ content of the melt and triggered the $\mathrm{Cu}-\mathrm{PGE}-\mathrm{Ag}$ sulfide mineralization during formation of the magnetite gabbro host-rock.
\end{abstract}

Keywords: Abitibi belt, Archean, igneous magnesiohastingsite, $\mathrm{H}$ isotope, magmatic degassing, ferropicrite, platinum-groupelement mineralization, Boston Creek, Ontario.

\section{SOMMAIRE}

Une analyse isotopique in situ de l'amphibole ignée provenant de la ferropicrite de Boston Creek, ceinture de l'Abitibi, en Ontario, une unité mafique-ultramafique de $100 \mathrm{~m}$ d'épaisseur, fournit une nouvelle information à propos de l'évolution de magmas archéens enrichis en $\mathrm{H}_{2} \mathrm{O}$, dérivés du manteau, et mis en place dans la croûte. Les analyses faites avec une microsonde ionique de la magnésiohastingsite interstitielle d'une roche ultramafique indique un grand intervalle de valeurs de $\delta \mathrm{D}$, allant de -47 à $+54 \%$ et une teneur de $2-3 \% \mathrm{H}_{2} \mathrm{O}$ (poids) à une échelle intragranulaire de 100 à $1000 \mu \mathrm{m}$, mais une composition relativement uniforme en termes des éléments majeurs et des éléments traces incompatibles. Ce grand intervalle dépasse largement les valeurs de $\delta \mathrm{D}$ obtenues pour les roches globales, $-50 \%$, les valeurs inférieures à $+10 \%$ o pour l'amphibole ignée des filonscouches ultramafiques, les valeurs entre -80 et $-30 \%$ o pour les fluides hydrothermaux-métamorphiques de la région, et les valeurs entre -90 et $-60 \%$ pour les matériaux du manteau. Les valeurs de $\delta \mathrm{D}$ anomalement élevées ne sauraient être attribuées à la seule perte de $\mathrm{H}$ de l'amphibole au cours de sa recristallisation secondaire. Le contraste avec la composition et les teneurs en $\mathrm{H}_{2} \mathrm{O}$ et

\$ E-mail address: wstone@nevadastar.com 
en éléments traces relativement uniformes excluent la possibilité que les valeurs de $\delta \mathrm{D}$ témoignent d'un fractionnement variable entre phase fluide et minéral. C'est plutôt à la composition du magma ferropicritique à partir duquel l'amphibole s'est formée que nous attribuons les valeurs anomalement élevées en $\delta \mathrm{D}$. Compte tenu de la distribution répandue et de l'abondance des bulles dans la ferropicrite de Boston Creek, ces values semblent indiquer un dégazage de l'hydrogène par rapport au deutérium, possiblement par dissociation de $\mathrm{H}_{2} \mathrm{O}$ pendant la mise en place du magma à faible profondeur dans la croûte. L'augmentation en degré d'oxydation du magma résiduel qui en résulta a causé la cristallisation d'un oxyde $\mathrm{Fe}-\mathrm{Ti}$, ce qui diminua la teneur en $\mathrm{FeO}$ du magma et déclencha une minéralisation en sulfures de $\mathrm{Cu}-\mathrm{PGE}-\mathrm{Ag}$ associée à la formation du gabbro à magnétite, la roche hôte.

(Traduit par la Rédaction)

Mots-clés: ceinture de l'Abitibi, archéen, magnésiohastingsite ignée, isotope de H, dégazage magmatique, ferropicrite, minéralisation en éléments du groupe du platine, Boston Creek, Ontario.

\section{INTRODUCTION}

Recent field, geochemical and experimental studies have led to the inference that some Archean ultrabasic melts were hydrous (Stone et al. 1997, Parman et al. 1997, Beresford et al. 2000). The $\mathrm{H}_{2} \mathrm{O}$ may have been derived by melting of hydrous mantle or by assimilation of crustal material during ascent and emplacement of the magma (Stone et al. 2003, Inoue et al. 2000, Litasov et al. 2001, Parman et al. 2001, Wilson 2003). If magmatic, the presence of $\mathrm{H}_{2} \mathrm{O}$ in the melts has major implications for the thermal evolution of the Earth (Grove \& Parman 2004). However, the nature, composition and distribution of volatiles in the Archean mantle and ultramafic melts remain poorly constrained. An important step in advancing the understanding of putative hydrous source-rocks in the mantle and processes of "wet" melting is to first examine the effects of crustal-level processes, such as magmatic degassing and hydrothermal alteration, on volatile composition and distribution in ultramafic melts.

In this study, we present new data on the evolution of hydrogen isotope compositions in Archean mantlederived melts emplaced in the crust. Ion-probe data are presented on the hydrogen isotope composition and $\mathrm{H}_{2} \mathrm{O}$ and trace-element contents of relict igneous amphibole from the Boston Creek ferropicrite, exposed near Kirkland Lake, Abitibi Belt, Ontario. This major unit is a layered peridotite-gabbro and spinifex-textured body $100 \mathrm{~m}$ thick (Stone et al. 1995a, b), which contains magmatic $\mathrm{Cu}-\mathrm{PGE}-\mathrm{Ag}$ sulfide mineralization in magnetite gabbro (Stone et al. 1992, 1993, 1996). The nature and origin of anomalously high $\delta \mathrm{D}$ values, up to $+54 \%$, are evaluated in the context of degassing during magmatic emplacement and postmagmatic hydrothermal alteration. The results have significant implications for the nature of Archean magmatic and postmagmatic processes and, possibly, for the origin of magnetite-gabbro-hosted $\mathrm{Cu}-\mathrm{PGE}-\mathrm{Ag}$ sulfide mineralization.

\section{Geological Setting}

The Boston Creek ferropicrite crops out on the east flank of the Round Lake Dome, in the southern part of the Abitibi greenstone belt, Ontario (Fig. 1). As documented by Larson et al. (1998), the unit is folded about the dome and dips steeply to the east. It is cut by fault zones and appears to be structurally repeated in the hanging wall. The unit has also been metamorphosed under low-grade conditions. Regionally, the geological section has undergone hydrothermal alteration, regional deformation and epigenetic $\mathrm{Cu}-\mathrm{Au}$ mineralization (Stone et al. 1987). The effects of deformation are present mainly on the upper and lower contacts of the ferropicrite unit, and primary igneous textures and minerals are well preserved internally within the unit. Consequently, research has focused on melt petrogenesis (Stone et al. 1995b), internal differentiation (Stone et al. 1995a), and magmatic Cu-PGE-Ag sulfide mineralization (Stone et al. 1996).

Studies along twelve sections over a strike-length of $2.5 \mathrm{~km}$ indicate that the Boston Creek ferropicrite consists from base to top of a thin chilled margin, a thick peridotite layer, a thin clinopyroxenite layer, a thick complex gabbro layer, a very thick $(30 \mathrm{~m})$ clinopyroxene spinifex layer, and a thin upper vesicular chilled margin (Stone et al. 1995b, Crocket et al. 2005). The overprinting effects of deformation and limited exposure hamper determination of an extrusive versus a plutonic origin. Nevertheless, the anomalously large thickness of the spinifex-textured layer, extensive zones of vesiculation and presence of altered glass internally within the ferropicrite unit are features consistent with volcanic emplacement or shallow-level intrusion.

Geochemically, the Boston Creek ferropicrite unit has very high contents of $\mathrm{Fe}$ at high $\mathrm{Mg}$, and low $\mathrm{Al}$, high Ti, LREE, and $\mathrm{Nb}$ at low HREE, Y and Sc, and depleted $\mathrm{Sm}-\mathrm{Nd}$ and $\mathrm{Re}-\mathrm{Os}$ isotope compositions (Stone et al. 1995b, Walker \& Stone 2001). The element enrichments, together with high initial values of $\varepsilon_{\mathrm{Nd}}$ 


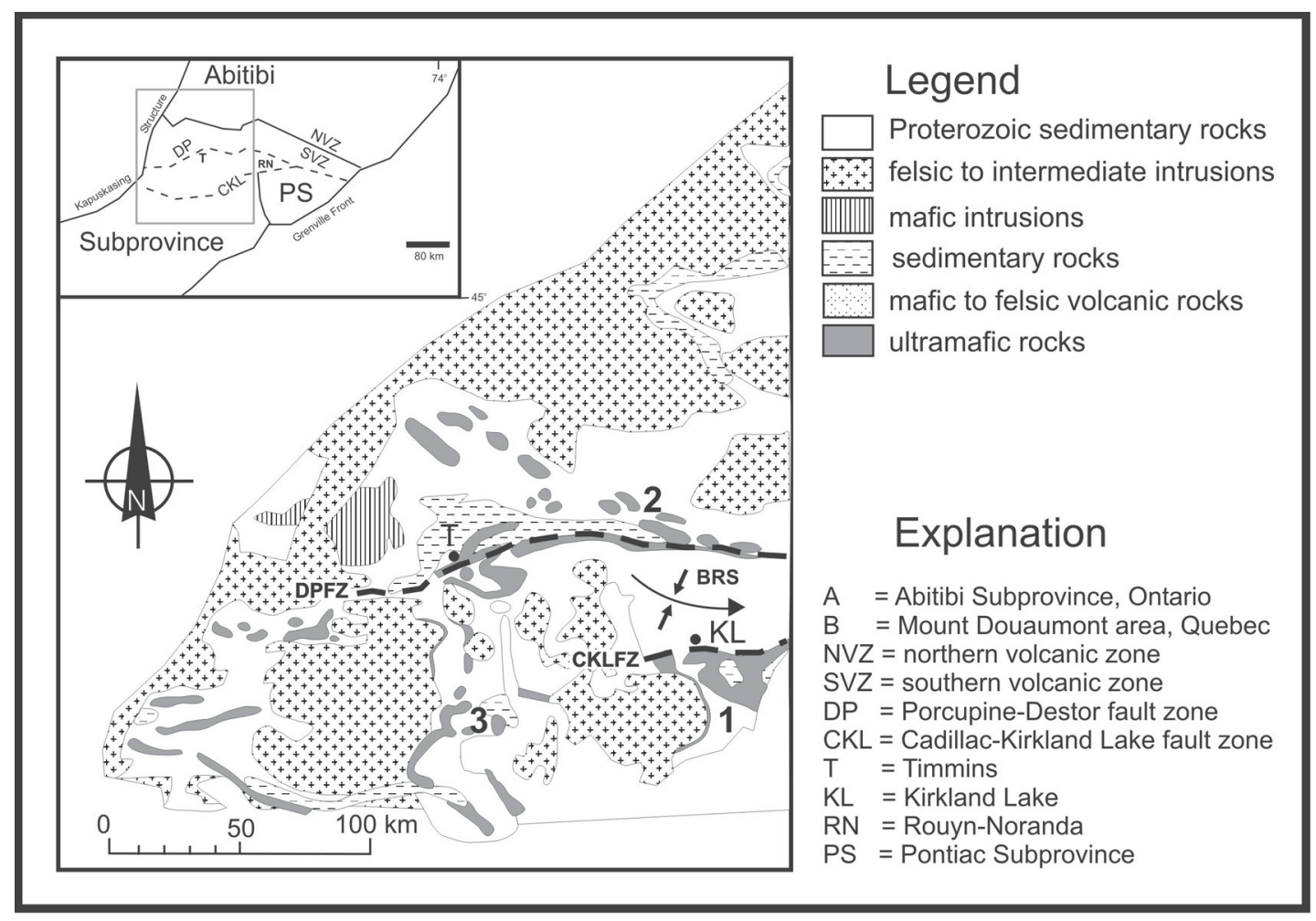

FIG. 1. The location and geological setting of the Boston Creek ferropicrite (BCF) in the Archean Abitibi greenstone belt, Ontario (Stone et al. 1987, Ayer \& Trowell 2000). Legend: 1: location of the Boston Creek ferropicrite; 2 and 3: locations of ultramafic sills, Munro-McCool townships and Sothman Township, respectively (Stone et al. 2003).

$(+2$ to +3 ; Stone et al. $1995 \mathrm{~b})$ and low initial $\gamma_{\mathrm{Os}}(-4$; Walker \& Stone 2001) are characteristics of melting of depleted mantle metasomatically enriched in $\mathrm{Nb}-\mathrm{LREE}$ and Fe-Ti by hydrous fluids.

Interestingly, the Boston Creek ferropicrite contains magmatic $\mathrm{Cu}-\mathrm{PGE}-\mathrm{Ag}$ sulfide mineralization in the margins of the gabbro layer (Fig. 2; Stone et al. 1992, 1993, 1996). The mineralization (up to 2 ppm PGE + $\mathrm{Ag}+\mathrm{Au}$ ) is hosted in podiform bodies of vari-textured magnetite gabbro with up to $15-20$ modal \% magnetite + ilmenite and up to 20 modal \% vesicles. Micrometric grains of Pd, Pt and Rh tellurides, bismuthotellurides and arsenides, Ag tellurides and selenides, and native $\mathrm{Au}$ and $\mathrm{Au}-\mathrm{Ag}$ alloy occur in chalcopyrite and pyrite grains disseminated within lamellar intergrowths of magnetite and ilmenite and secondary silicates. The mineralization zones formed by in situ concentration of PGE-Ag-rich $\mathrm{Fe}-\mathrm{Cu}$ sulfide with $\mathrm{Fe}-\mathrm{Ti}$ oxide along the margins of internal dynamic melt-channels (Stone et al. 1996).

\section{EXPERIMENTAL METHODS}

The abundance and good preservation of relict igneous amphibole make the Boston Creek ferropicrite ideal for petrographic and geochemical studies of this phase (Stone et al. 1995b, 2003). Igneous amphibole is widespread in the unit and present in minor to major modal amounts of relict grains of micrometric to millimetric size. The phase is most abundant in the ultramafic layers, where it forms interstitial grains up to $500 \mu \mathrm{m}$ in diameter at the margin of metamorphic amphibole pseudomorphs of clinopyroxene grains (Fig. 3) and grains enclosing serpentine pseudomorphs of olivine grains. The preserved igneous textures and the very high Ti content of the magnesiohastingsite (see below) indicate a high-temperature origin (Spear 1981). The low-grade metamorphic amphibole has a much lower Ti content. The relict igneous amphibole analyzed for this study is from fine- to medium-grained rock in the transitional zone between the basal chilled margin below and the peridotite layer above. The lack of suitable standards precluded isotopic analysis of the metamorphic amphibole.

Major-element compositions of the igneous amphibole were determined with a JEOL JXA-8600/3 electron probe micro-analyzer at the University of Alabama (Tuscaloosa). The analyses were generated with a beam size of $1 \mu \mathrm{m}$, Faraday cup current of $20 \mathrm{nA}$, an accelera- 


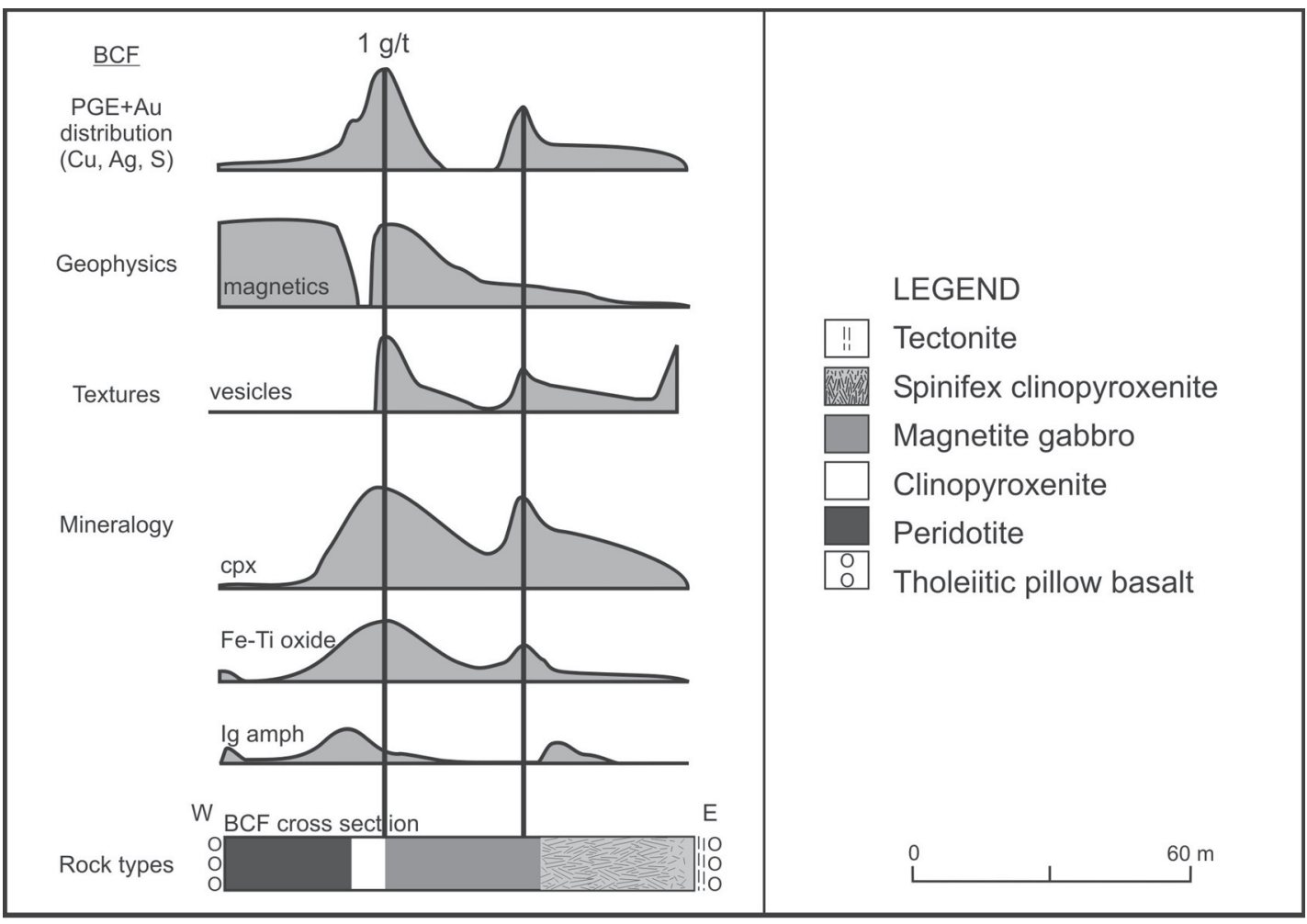

FIG. 2. The internal setting of the disseminated Cu-PGE-Ag sulfide mineralization in the lower and upper margins of the central magnetite gabbro layer. The position of the mineralization coincides with markedly higher allied metal contents, positive magnetic susceptibility, and higher modal proportions of vesicles, clinopyroxene and magnetite + ilmenite.

ting voltage of $15 \mathrm{kV}$, and wavelength-dispersion techniques. Natural silicate, oxide, and phosphate minerals and glass were utilized as standards. Replicate analyses of the standards indicate accuracy and precision errors of $\leq 0.5 \mathrm{wt} \%$ in relative value. The analytical results were reduced employing the recommendations of Leake et al. (1997). The procedure employed for calculation of $\mathrm{Fe}^{3+}$ and $\mathrm{Fe}^{2+}$ is that of Rock \& Leake (1997), and produces values close to those accurately measured in $80 \%$ of the compositions studied.

The igneous amphibole was analyzed in situ for $\mathrm{H}_{2} \mathrm{O}$, $\mathrm{D} / \mathrm{H}$ ratio and trace elements on a modified CAMECA IMS $3 f$ ion microprobe at the CRPG-CNRS (Nancy). The $\mathrm{H}_{2} \mathrm{O}$ analyses were carried out following the techniques of Deloule et al. (1991a, 1995). The analytical uncertainty is $<10 \%$ in relative value. The analytical procedure for the hydrogen isotope analysis is that of Deloule et al. (1991b). A negative primary oxygen beam is focused to $10 \mu \mathrm{m}$ on carefully selected spots on the amphibole grains. Standards are analyzed prior to and following analysis of each sample. The standards are utilized to establish the relationship of the mean mass- to-charge ratio $(\mathrm{M} / \mathrm{C})$ of the octahedrally coordinated cations and the instrumental $\mathrm{D} / \mathrm{H}$ fractionation factor. The precision for the $\delta \mathrm{D}$ values measured through this calibration method, calculated from replicate analysis of standard minerals, is better than $\pm 12 \%$, including the possible spatial heterogeneity of the standards. For amphibole, ion-probe measurements of $\mathrm{D} / \mathrm{H}$ are independent of crystallographic orientation, at least to the analytical precision of the probe ( $c f$. Deloule et al. 1991b). The concentration of the rare-earth elements (REE) and of the high field-strength elements (HFSE) were obtained following the techniques of Gurenko \& Chaussidon (1995). Replicate analyses of the Kakanui clinopyroxene standard indicate an accuracy of $\pm 5-15 \%$ for $\mathrm{Ba}, \mathrm{Sr}, \mathrm{La}, \mathrm{Ce}, \mathrm{Nd}, \mathrm{Sm}$, and $\mathrm{Dy}$, and $\pm 15-25 \%$ for $\mathrm{Nb}, \mathrm{Gd}, \mathrm{Er}$ and $\mathrm{Yb}$.

\section{RESULTS}

Geochemical analyses of petrographically similar grains of relict igneous amphibole indicate relatively uniform intragrain and intergrain contents of major 


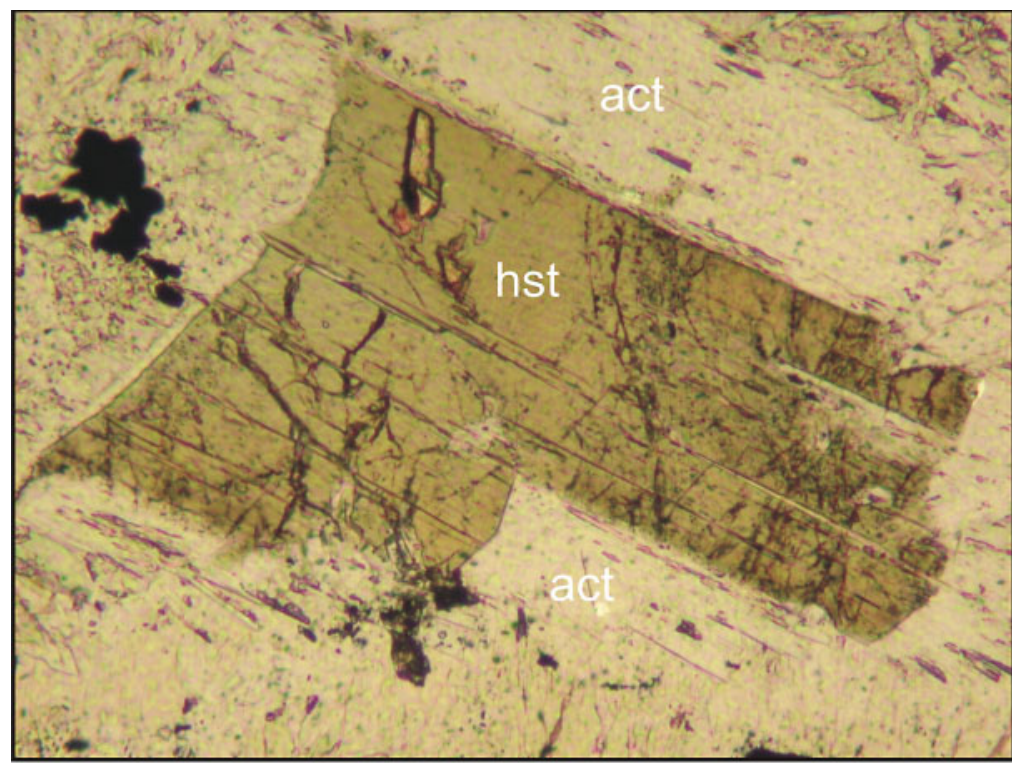

FIG. 3. Large relict igneous amphibole (hst) and finer-grained secondary metamorphic amphibole (act) due to alteration at the margins of replaced clinopyroxene (plane-polarized light, field of view: $1.2 \mathrm{~mm}$ ). Symbols: hst: magnesiohastingsite, act: actinolite.

elements, trace elements and $\mathrm{H}_{2} \mathrm{O}$, but markedly variable $\delta \mathrm{D}$ compositions (Tables $1-3$ ). Contents of total iron oxide (12 wt\% FeO), magnesium oxide (13 wt $\% \mathrm{MgO})$, aluminum oxide (11-12 wt $\left.\% \mathrm{Al}_{2} \mathrm{O}_{3}\right)$, and titanium oxide $\left(3 \mathrm{wt} \% \mathrm{TiO}_{2}\right)$ are high relative to silicon oxide (41-43 wt\% $\mathrm{SiO}_{2}$ ), and the grains lack zonation (Table 1). Contents of $\mathrm{Fe}^{3+}$ are greater than ${ }^{\mathrm{VI}} \mathrm{Al}$ (Fig. 4) and, in the classification scheme of Leake et al. (1997), the igneous amphibole is magnesiohastingsite in composition. Primitive mantle-normalized profiles peak at $\mathrm{Nb}-\mathrm{La}$ and show strong enrichment in the light REE (LREE) relative to the heavy REE (HREE) $\left[(\mathrm{La} / \mathrm{Yb})_{\mathrm{n}}\right.$ between 10 and 15)] (Table 2, Fig. 5). These profiles are similar to those for the ferropicrite whole-rock samples (Stone et al. 1995b), but differ from the flatter $\left[(\mathrm{La} / \mathrm{Yb})_{\mathrm{n}}\right.$ in the range 0.6-5.0] and more irregular profiles (e.g., negative Sr anomalies) for the Archean ultramafic sills in the area (Fig. 5). The contents of $\mathrm{H}_{2} \mathrm{O}$ range from 1.7 to $4.1 \mathrm{wt} \%$ (Table 3 ). With a mean value of $2.6 \pm 0.6$ $\mathrm{wt} \%$, the $\mathrm{H}_{2} \mathrm{O}$ contents are at the high end for igneous amphiboles.

In contrast to the major- and trace-element and $\mathrm{H}_{2} \mathrm{O}$ contents, the $\delta \mathrm{D}$ compositions at the same four spots on the amphibole grains show marked heterogeneity (Table 3). The $\delta \mathrm{D}$ values for three points on grain 1a vary from $+22 \%$ o to $+54 \%$, four points on grain $1 \mathrm{~b}$ vary from $-28 \%$ to $+7 \%$, three points on grain 2 a vary from $-4 \%$ o to $+21 \%$ o, and three points on grain $3 \mathrm{~b} / \mathrm{a}$ vary from $-47 \%$ o to $-4 \%$. Overall, the $\delta \mathrm{D}$ values measured for the amphibole grains range from $-47 \%$ o to $+54 \%$ o (Fig. 6). This range is much higher than the $\delta \mathrm{D}$ values of $-50 \%$ for whole-rock samples (mixture of relict igneous and secondary metamorphic minerals), values for hydrothermal-metamorphic fluids in the area $(-80$ to $-30 \%$; McCuaig \& Kerrich 1998) and elsewhere (Taylor 1974), and range of generally acceptable values for mantle materials (-90 to $-60 \%$; Sheppard \& Epstein 1970, Taylor, H.P. 1986, Garcia et al. 1989). The variations at the grain scale are well beyond analytical error $(12 \%)$. They cannot be attributed to variations in the instrumental mass-fractionation factor applied to the raw ion-probe $\mathrm{D} / \mathrm{H}$ measurements, because of the uniform major-element and incompatible trace-element contents of the grain spots analyzed.

The magnitude of the $\delta \mathrm{D}$ variation within single grains of amphibole from the ferropicrite resembles that of igneous amphiboles from other ultramafic rocks elsewhere (Fig. 7, Deloule et al. 1991a, Wagner et al. 1996, Valley et al. 1998, Stone et al. 2003), though it is smaller than that for the Cenozoic Nushan amphibole ( -94 to $46 \%$; Xia et al. 2002). Seven of the thirteen points gave positive $\delta \mathrm{D}$ values, up to $+54 \%$, much higher than the $+8 \%$ value of the inclusion amphibole in ultramafic sills of this area (Stone et al. 2003) and the $+8 \%$ value of megacryst amphibole from the Cima basanite (Boettcher \& O'Neil 1980), though similar to the $+46 \%$ value for Nushan amphibole (Xia et al. 2002) (Fig. 7). Indeed, the ultramafic sills in the area under- 
went low-grade metamorphism, like the Boston Creek ferropicrite, yet have significantly more negative (i.e., lighter) or "normal" $\delta \mathrm{D}$ values. Consequently, the less negative and positive $\delta \mathrm{D}$ values for the ferropicrite unit are significantly anomalous and warrant further study.

\section{DisCUSSION}

The wide range of $\delta \mathrm{D}$ values for the igneous amphibole from the Boston Creek ferropicrite contrasts with the relatively uniform contents of major and trace elements and $\mathrm{H}_{2} \mathrm{O}$ in the grains. The unaltered nature of the analyzed amphibole and their distinctive $\delta \mathrm{D}$ values $(-47$ to $+54 \%$ ) , compared to the whole-rock values $(-50 \%)$ and to amphibole from similarly altered

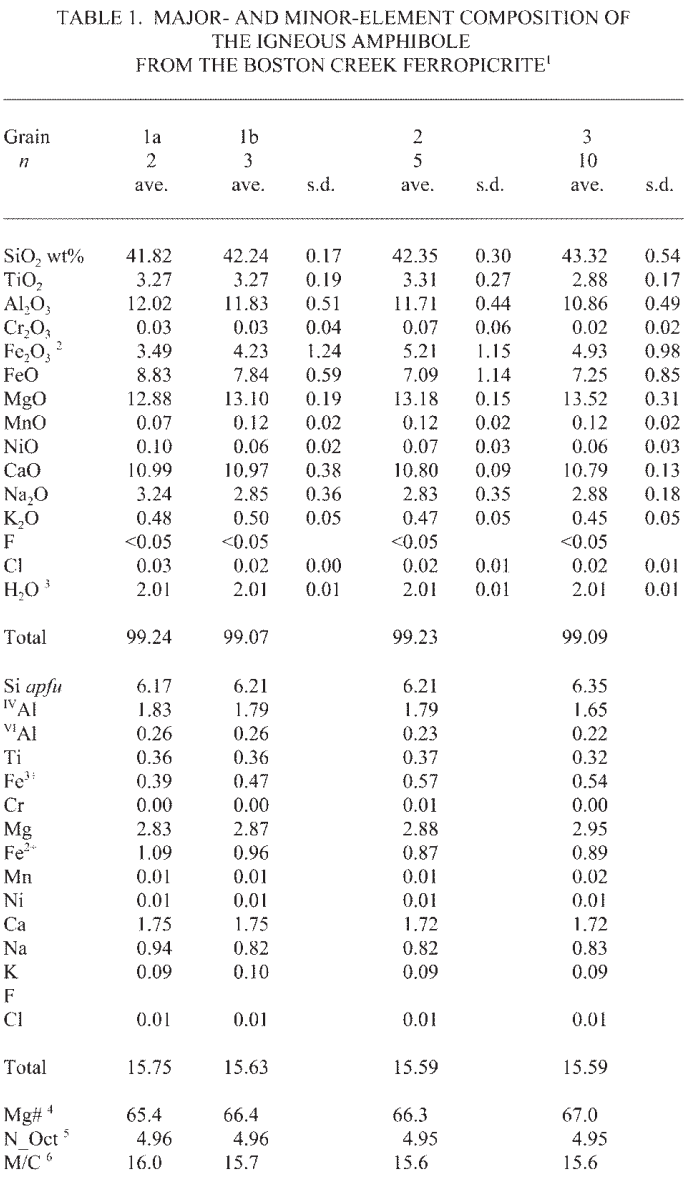

The analyses were made by electron-microprobe wavelength-dispersion (WDS) techniques.

"The amounts of $\mathrm{Fe}^{3+}$ and $\mathrm{Fe}^{2 *}$ are calculated assuming $23 \mathrm{O}$ per formula unit and th 13 cations anding $\mathrm{Ca}$, $\mathrm{Na}$ and $\mathrm{K}$.

${ }^{3}$ The amount of $\mathrm{H}_{2} \mathrm{O}$ is calculated assuming stoichiomctry.

${ }^{4} \mathrm{MgH}=100 * \mathrm{Mg} /\left(\mathrm{Mg}+\mathrm{Fe}^{2+}+\mathrm{Fe}^{3+}+\mathrm{Mn}+\mathrm{Ni}\right)$.

${ }^{5} \mathrm{~N}$ Oct $={ }^{\mathrm{VI}} \mathrm{Al}+\mathrm{Ti}+\mathrm{Cr}+\mathrm{Fe}^{3+}+\mathrm{Fe}^{2+}+\mathrm{Mg}+\mathrm{Mn}+\mathrm{Ni}$.

$\mathrm{M} / \mathrm{C}=$ mean mass-to-charge ratio of the octahedrally coordinated cations. and metamorphosed ultramafic sills in the area $(-125$ to $+10 \%$ ) , exclude the possibility that the $\delta \mathrm{D}$ variations reflect hydrogen exchange during postmagmatic hydrothermal and metamorphic processes (e.g., Xia et al. 2002, Stone et al. 2003). For example, the $\delta \mathrm{D}$ mean value of $-80 \%$ or for relict igneous amphibole from

TABLE 2. TRACE-ELEMENT CONTENTS OF THE IGNEOUS AMPHIBOLE, AS MEASURED BY ION PROBE

\begin{tabular}{lccccccc}
\hline & & & & & & & \\
Grain & $1 \mathrm{~b}$ & $1 \mathrm{~b}$ & $1 \mathrm{~b}$ & $2 \mathrm{a}$ & $2 \mathrm{~b}$ & $3 \mathrm{~b}$ & $3 \mathrm{~b}$ \\
$\mathrm{Spot}$ & 1 & 2 & 3 & 1 & 1 & 1 & 2 \\
\hline & & & & & & & \\
$\mathrm{Bappm}$ & 158 & 234 & 541 & 234 & 154 & 173 & 170 \\
$\mathrm{Nb}$ & 67.9 & 119 & 97.9 & 85.6 & 65.1 & 100 & 55.5 \\
$\mathrm{La}$ & 60.4 & 69.0 & 62.8 & 78.8 & 43.7 & 49.6 & 60.9 \\
$\mathrm{Ce}$ & 184 & 262 & 211 & 220 & 154 & 164 & 190 \\
$\mathrm{Pr}$ & 18.4 & 27.6 & 22.5 & 20.0 & 15.4 & 16.0 & 17.3 \\
$\mathrm{Sr}$ & 1057 & 1362 & 1171 & 1526 & 1020 & 1126 & 1154 \\
$\mathrm{Nd}$ & 71.2 & 112.6 & 89.2 & 76.2 & 60.2 & 55.4 & 63.4 \\
$\mathrm{Sm}$ & 12.3 & 22.4 & 18.9 & 14.4 & 11.0 & 10.7 & 11.3 \\
$\mathrm{Eu}$ & 2.2 & 6.2 & 5.9 & 3.6 & 6.7 & 3.6 & 3.4 \\
$\mathrm{Zr}$ & 250 & 366 & 390 & 294 & 160 & 304 & 187 \\
$\mathrm{Hf}$ & 4.0 & $<1.00$ & 2.5 & 2.5 & 1.7 & 2.3 & 3.0 \\
$\mathrm{Ti}$ & 17187 & 18752 & 20114 & 23827 & 10872 & 18523 & 14314 \\
$\mathrm{Gd}$ & 9.6 & 19.1 & 12.3 & 11.6 & 7.0 & 9.1 & 8.5 \\
$\mathrm{Dy}$ & 10.4 & 17.4 & 13.2 & 10.3 & 7.1 & 8.3 & 8.8 \\
$\mathrm{Y}$ & 59.9 & 99.1 & 66.5 & 65.6 & 44.7 & 53.7 & 52.0 \\
$\mathrm{Er}$ & 4.6 & 7.2 & 6.0 & 5.6 & 3.6 & 3.8 & 4.1 \\
$\mathrm{Yb}$ & 4.0 & 5.0 & 4.0 & 4.0 & 3.1 & 2.9 & 3.2 \\
$\mathrm{Lu}$ & 0.3 & 0.5 & 0.4 & 0.4 & 0.2 & 0.2 & 0.3 \\
$\mathrm{~V}$ & 325 & 243 & 256 & 342 & 170 & 247 & 211 \\
$\mathrm{Sc}$ & 26.9 & 13.4 & 13.1 & 21.0 & 15.3 & 13.6 & 17.7 \\
& & & & & & & \\
$(\mathrm{La} / \mathrm{Yb})_{n}$ & 10.71 & 9.93 & 11.25 & 14.10 & 10.05 & 12.25 & 13.50 \\
$(\mathrm{La} / \mathrm{Sm})_{n}$ & 3.16 & 1.99 & 2.15 & 3.55 & 2.56 & 2.99 & 3.49 \\
$(\mathrm{Gd} / \mathrm{Yb})_{n}$ & 1.97 & 3.16 & 2.54 & 2.39 & 1.85 & 2.60 & 2.18 \\
& & & & & & & \\
& & & & & & &
\end{tabular}

TABLE 3. AMOUNT OF $\mathrm{H}_{2} \mathrm{O}$ AND H ISOTOPE COMPOSITIONS OF IGNEOUS AMPHIBOLE FROM THE BOSTON CREEK FERROPICRITE

\begin{tabular}{|c|c|c|c|c|c|c|c|c|c|c|}
\hline \multicolumn{2}{|c|}{$\begin{array}{l}\text { Area, } \\
\text { grain }\end{array}$} & Spot & $\begin{array}{c}X \\
\mu \mathrm{m}\end{array}$ & $\begin{array}{c}\mathrm{Y} \\
\mu \mathrm{m}\end{array}$ & $\begin{array}{l}\mathrm{H}_{2} \mathrm{O} \\
\mathrm{wt} \% \%\end{array}$ & $\mathrm{D} / \mathrm{Hc}$ & s.d. & $\mathrm{M} / \mathrm{C}$ & \multicolumn{2}{|c|}{$\mathrm{D} / \mathrm{HV} \mathrm{D}_{\mathrm{smOW}}$} \\
\hline & a & 1 & -3126 & -3919 & 2.73 & 106.5 & 1.1 & 16 & 164.2 & 54 \\
\hline & & 2 & -3381 & -3884 & 2.09 & 103 & 1.2 & 16 & 159.2 & 22 \\
\hline & & 3 & -6040 & -226 & n.d. & 105.2 & 1.1 & 16 & 162.1 & 40 \\
\hline & & & & & & & \multicolumn{2}{|c|}{ average } & & 38 \\
\hline \multirow[t]{5}{*}{1} & b & 4 & -5577 & -31.64 & 1.65 & 100.0 & 1.1 & 16 & 152.9 & -18 \\
\hline & & 5 & -5654 & -300 & 4.05 & 99. & 1.1 & 16 & 151.4 & -28 \\
\hline & & 6 & -6562 & -217 & 2.59 & 102 & 1.3 & 16 & 156.8 & 6 \\
\hline & & 7 & -5819 & -1846 & 1.93 & 102.5 & 1.2 & 16 & 156.8 & 7 \\
\hline & & & & & & & \multicolumn{2}{|c|}{ average } & & -8 \\
\hline \multirow[t]{4}{*}{2} & a & 1 & 2470 & -4661 & 2.58 & 104.3 & 1.1 & 16 & 159.1 & 21 \\
\hline & & 2 & 2386 & -4324 & 2.41 & 103 & 1.3 & 16 & 158.3 & 16 \\
\hline & & 3 & 2608 & -4300 & 3.07 & 101.7 & 1.2 & 16 & 155.2 & -4 \\
\hline & & & & & & & \multicolumn{2}{|c|}{ average } & & 11 \\
\hline \multirow[t]{3}{*}{3} & $b / a$ & 1 & 3390 & 4860 & 2.43 & 101.7 & 1.2 & 16 & 155.1 & -4 \\
\hline & & 2 & 3590 & 5025 & 2.94 & 100 & 1. & 16 & 153.1 & -17 \\
\hline & & 3 & 3650 & 5178 & 2.85 & 97.3 & 1.1 & 16 & 148.5 & -47 \\
\hline
\end{tabular}

The analyses were made by ion-probe techniques. D/Hc: D/H value neasured by ion probe; $\mathrm{D} / \mathrm{Hv}$ : $\mathrm{D} / \mathrm{H}$ value corrected for instrumental fractionation. The standard deviation, s.d., includes statistical and calibration errors. $\mathrm{M} / \mathrm{C}$ : mean mass-to-charge ratio of the octahedrally coordinated cations. 

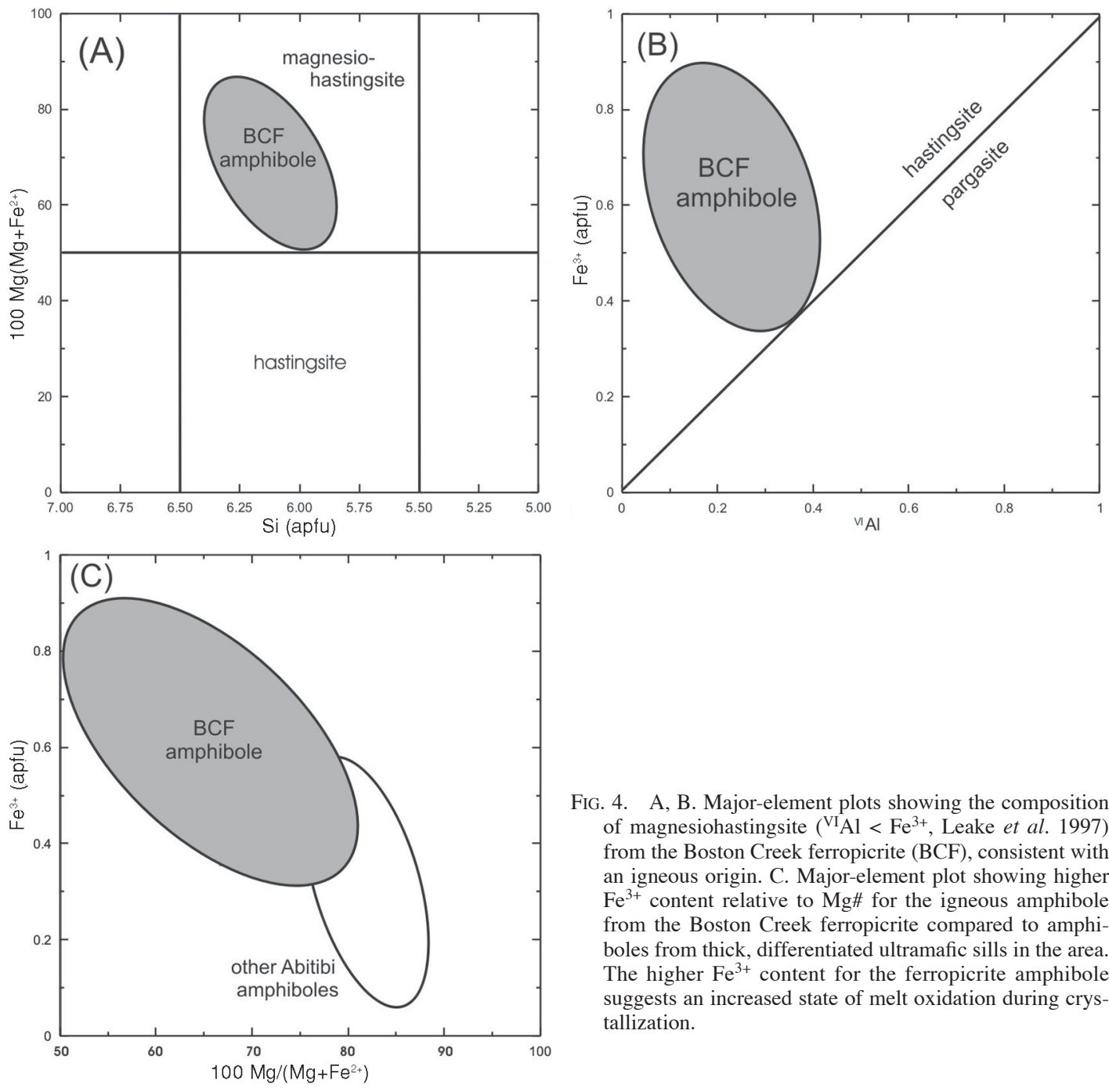

FIG. 4. A, B. Major-element plots showing the composition of magnesiohastingsite ( ${ }^{\mathrm{VI}} \mathrm{Al}<\mathrm{Fe}^{3+}$, Leake et al. 1997) from the Boston Creek ferropicrite (BCF), consistent with an igneous origin. C. Major-element plot showing higher $\mathrm{Fe}^{3+}$ content relative to $\mathrm{Mg} \#$ for the igneous amphibole from the Boston Creek ferropicrite compared to amphiboles from thick, differentiated ultramafic sills in the area. The higher $\mathrm{Fe}^{3+}$ content for the ferropicrite amphibole suggests an increased state of melt oxidation during crystallization.

the basal chilled margin of a major ultramafic unit in Sothman Township (i.e., Location 3 in Fig. 1) is much more strongly negative than any of the values for the Boston Creek ferropicrite. Furthermore, hydrogen exchange with meteoric water would result in negative, not positive $\delta \mathrm{D}$ values. Consequently, the $\delta \mathrm{D}$ values for the amphibole in the ferropicrite most probably record a magmatic process.

\section{Magma degassing}

Considering the nature and abundance of vesicles within the Boston Creek ferropicrite, the anomalously high $\delta \mathrm{D}$ values can plausibly be explained by $\mathrm{H}$ loss through degassing prior to or during crystallization.

Large inter-species fractionation-factors are expected; thus it is possible to cause significant variation in $\delta \mathrm{D}$ by fractionation among different hydrogen species (e.g., $\mathrm{H}_{2} \mathrm{O}, \mathrm{H}_{2}, \mathrm{H}_{2} \mathrm{~S}, \mathrm{HCl}$ ) during degassing. Laboratory studies (Pineau et al. 1998) indicate hydrogen isotopic fractionation between water vapor $\left(\mathrm{H}_{2} \mathrm{O}\right)$ and melt $\left(\Delta \mathrm{D}_{\mathrm{H} 2 \mathrm{O}-\text { melt }}\right)$ can exceed $+40 \%$. Hydrogen isotopic fractionation-factors between reduced gases (e.g., $\mathrm{H}_{2}, \mathrm{H}_{2} \mathrm{~S}$, $\mathrm{HCl}$ ) and melt can be less than $-150 \%$ (Pineau et al. 1998, Xia et al. 2002). In more recent terranes, outgassing of $\mathrm{H}$ is common during basalt emplacement (Sato \& Wright 1966, Mathez 1984, Christie et al. 1986).

The proposed process of degassing in Boston Creek ferropicrite can be modeled to explain the $\mathrm{H}$ isotope compositions of its igneous amphibole. Partial melting 


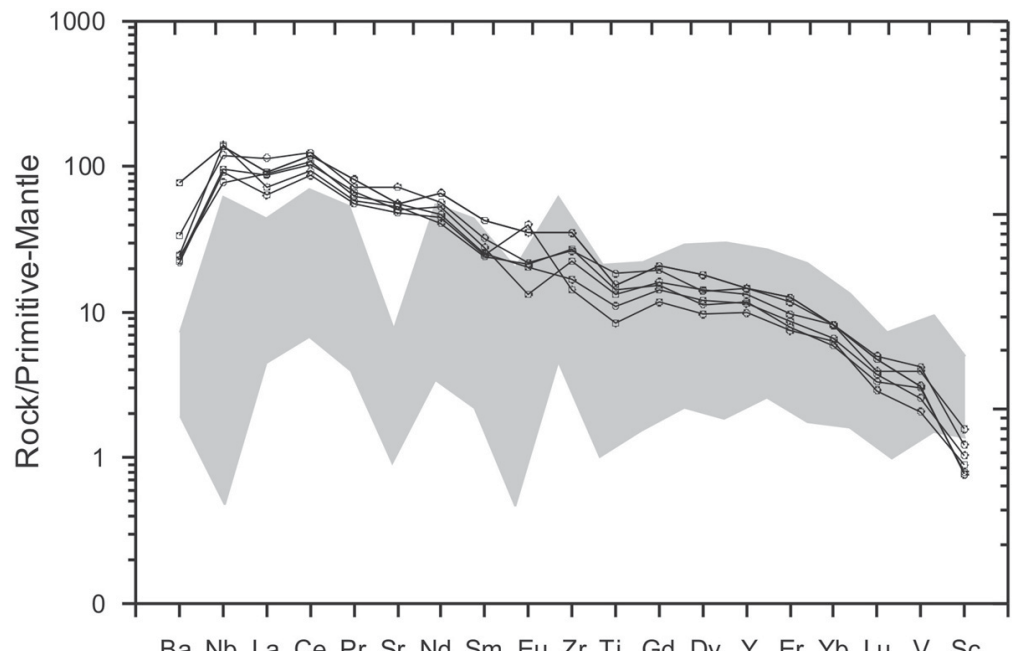

FIG. 5. Primitive mantle-normalized trace-element concentrations of the igneous amphibole from the Boston Creek ferropicrite. The shaded field represents the levels of trace elements of igneous amphiboles from ultramafic sills in the area (Stone et al. 2003). The normalization values are those of McDonough \& Frey (1989) and Sun \& McDonough (1989).

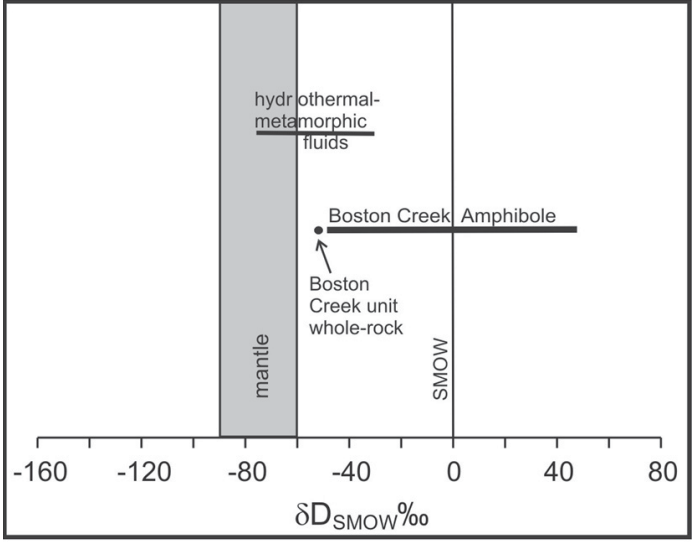

FIG. 6. Schematic summary of the range of values for $\delta \mathrm{D} \%$ o determined via in situ SIMS analyses of the igneous amphibole from the Boston Creek ferropicrite compared to whole-rock values (W.E. Stone, unpubl. data), hydrothermal-metamorphic fluids ( -80 to $-30 \%$; McCuaig \& Kerrich 1998) in the area, mantle materials ( -90 to $-60 \%$ ), and seawater (SMOW) (Sheppard \& Epstein 1970, Taylor, H.P. 1974, 1986, Garcia et al. 1989). in the mantle would impart a primary hydrogenisotope composition on the melt. Gases escaped from the magma either as aqueous vapor $\left(\mathrm{H}_{2} \mathrm{O}\right)$ or reduced species (e.g., $\mathrm{H}_{2}, \mathrm{H}_{2} \mathrm{~S}, \mathrm{HCl}$, etc.) during emplacement. For $\mathrm{H}_{2} \mathrm{O}$, the $\mathrm{H}$ isotope fractionation between $\mathrm{H}_{2} \mathrm{O}$ and magma is positive $\left(\Delta \mathrm{H}_{\mathrm{gas}} / \mathrm{melt}>0\right)$, such that the escaping gas would be enriched in $\mathrm{D}$ and the residual magma progressively depleted in $\mathrm{D}$ during degassing. In this process, the $\delta \mathrm{D}$ values of the residual melt shift from an initial mantle value to more negative values. Obviously, this model cannot explain the anomalously high $\delta D$ values.

Alternatively, for reduced species, the $\mathrm{H}$ isotope fractionation between gas and magma is negative $\left(\Delta \mathrm{D}_{\text {gas/melt }}<0\right)$, such that escaped $\mathrm{H}$ gas would be isotopically lighter, with a lower $\delta \mathrm{D}$ value and residual $\mathrm{H}_{2} \mathrm{O}$ isotopically heavier, with a higher $\delta \mathrm{D}$. In this model, the values of $\delta \mathrm{D}$ for the residual magma shift from an initial mantle-type value to progressively higher and ultimately positive values during exsolution and degassing of volatiles, and the residual magma becomes more oxidized. This model explains the anomalously high $\delta \mathrm{D}$ values for the Boston Creek ferropicrite. Following Xia et al. (2002), the magnitude of change in the $\delta \mathrm{D}$ values can be modeled via the Rayleigh distillation equation 


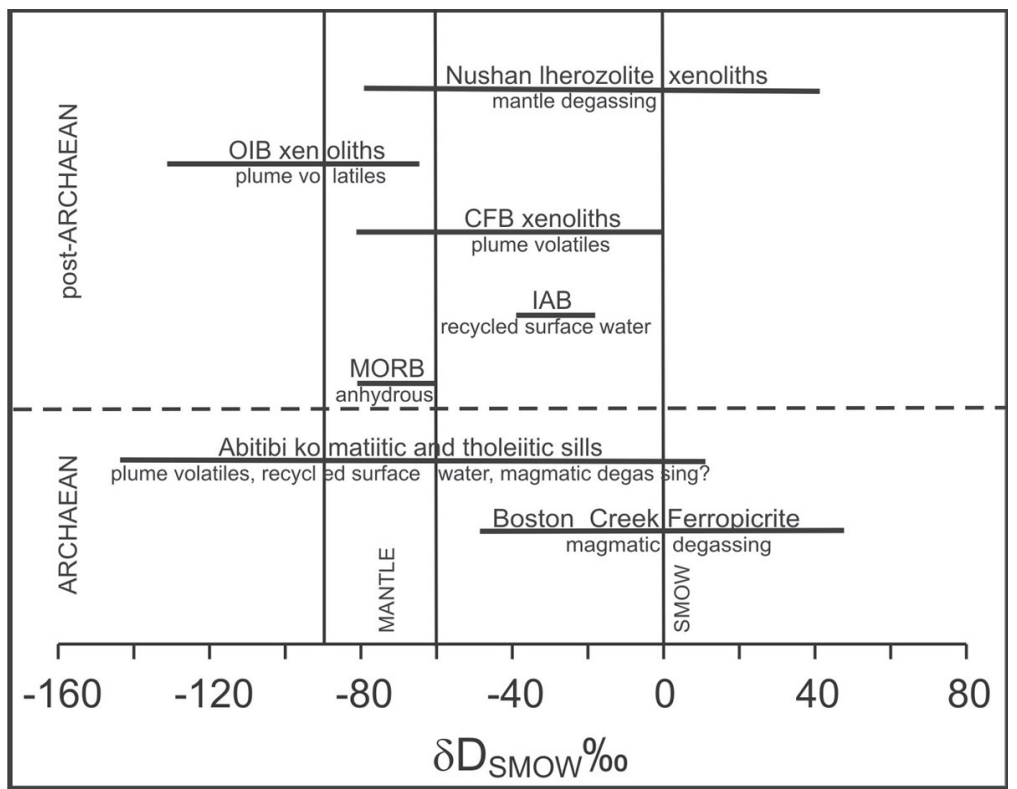

FIG. 7. Variation in $\delta \mathrm{D} \%$ values for igneous amphibole from the Boston Creek ferropicrite compared to other major rock-types globally. Values for the ferropicrite amphibole exceed SMOW and igneous amphiboles from other Abitibi units, and even the Nushan xenoliths (Deloule et al. 1991a, 1995, Wagner et al. 1995, Valley et al. 1998, Xia et al. 2002, Stone et al. 2003). Acronyms: MORB: mid-ocean-ridge basalts, IAB: island-arc basalt, CFB: continental flood basalt, and OIB: ocean-island basalt.

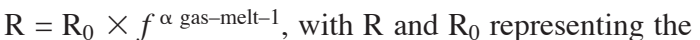
residual and initial ratios of the heavy to light isotopes, $f$ is the fraction of $\mathrm{H}_{2} \mathrm{O}$ in the residual melt, and $\alpha_{\text {gas-melt }}$ is the $\mathrm{H}$ isotope fractionation-factor. The isotope fractionation between gas and melt $\left(\Delta \mathrm{D}_{\text {gas-melt }}\right)$ is assumed to be $-130 \%$ and $-220 \%$ at $1000^{\circ}$ and $700^{\circ} \mathrm{C}$, respectively (Taylor, B.E. 1986). The primary $\delta \mathrm{D}$ of magma is set at $-60 \%$, a generally acceptable mantle-type value (Sheppard \& Epstein 1970, Taylor, H.P. 1986). If the fraction of residual $\mathrm{H}_{2} \mathrm{O}$ in the melt $(f)$ is 0.41 and 0.57 , respectively, the value of the model ratio $\delta \mathrm{D}$ is $+50 \%$ o (Table 4, Fig. 8), in agreement with the highest value determined for Boston Creek amphibole. The fractionation factor between amphibole and melt is minor (Xia et al. 2002), such that the $\delta \mathrm{D}$ values for the amphibole should be similar to that of the parental melt.

\section{Oxidation and PGE mineralization}

A potential mechanism for the degassing of $\mathrm{H}$ from the Boston Creek ferropicrite is dissociation of $\mathrm{H}_{2} \mathrm{O}$, as follows: $\mathrm{H}_{2} \mathrm{O}$ (melt) $\rightarrow \mathrm{H}_{2}$ (gas) $+1 / 2 \mathrm{O}_{2}$ (melt) (Sato \& Wright 1966, Mathez 1984). The preferential loss of $\mathrm{H}$ as $\mathrm{H}_{2}$ relative to $\mathrm{H}_{2} \mathrm{O}$ would result in oxidation of the residual degassed melt. Oxidation during progressive or episodic degassing is consistent with four major features of the ferropicrite unit: (1) $\mathrm{Fe}^{3+}$-enriched magnesiohastingsite composition of the igneous amphibole (e.g., Semet \& Ernst 1981), (2) high bulk modal abundance of magnetite + ilmenite (up to 20 modal \%; Stone et al. 1995b), (3) values of the ratio $\mathrm{Fe}^{3+}$ :total iron of 0.25 for whole-rock samples (Stone 1985), and (4) high contents of Pt in chromite (Stone \& Crocket 2003). The proposed oxidation of the residual melt is significant, because it could be a controlling factor in the origin of the $\mathrm{Cu}-\mathrm{PGE}-\mathrm{Ag}$ sulfide mineralization within the gabbro layer.

The close spatial association of the PGM, Ag minerals and $\mathrm{Cu}-\mathrm{Fe}$ sulfides with magnetite + ilmenite and vesicles within the magnetite gabbro host-rock all support a strong role for melt oxidation in the mineralization. Indeed, section 9, the most highly mineralized of the twelve sections studied (Stone et al. 1995a, 1996), is also the most highly vesicular (Fig. 9). The vesicles could represent, at least in part, volatiles derived by compaction of the underlying amphibole-bearing ultramafic cumulates and percolation of the hydrous interstitial melt upward to the interior level of formation of the gabbro layer. The medium-grained nature of the amphibole-bearing ultramafic rocks suggests that they may not have been fully crystallized during the formation of the magnetite gabbro. 


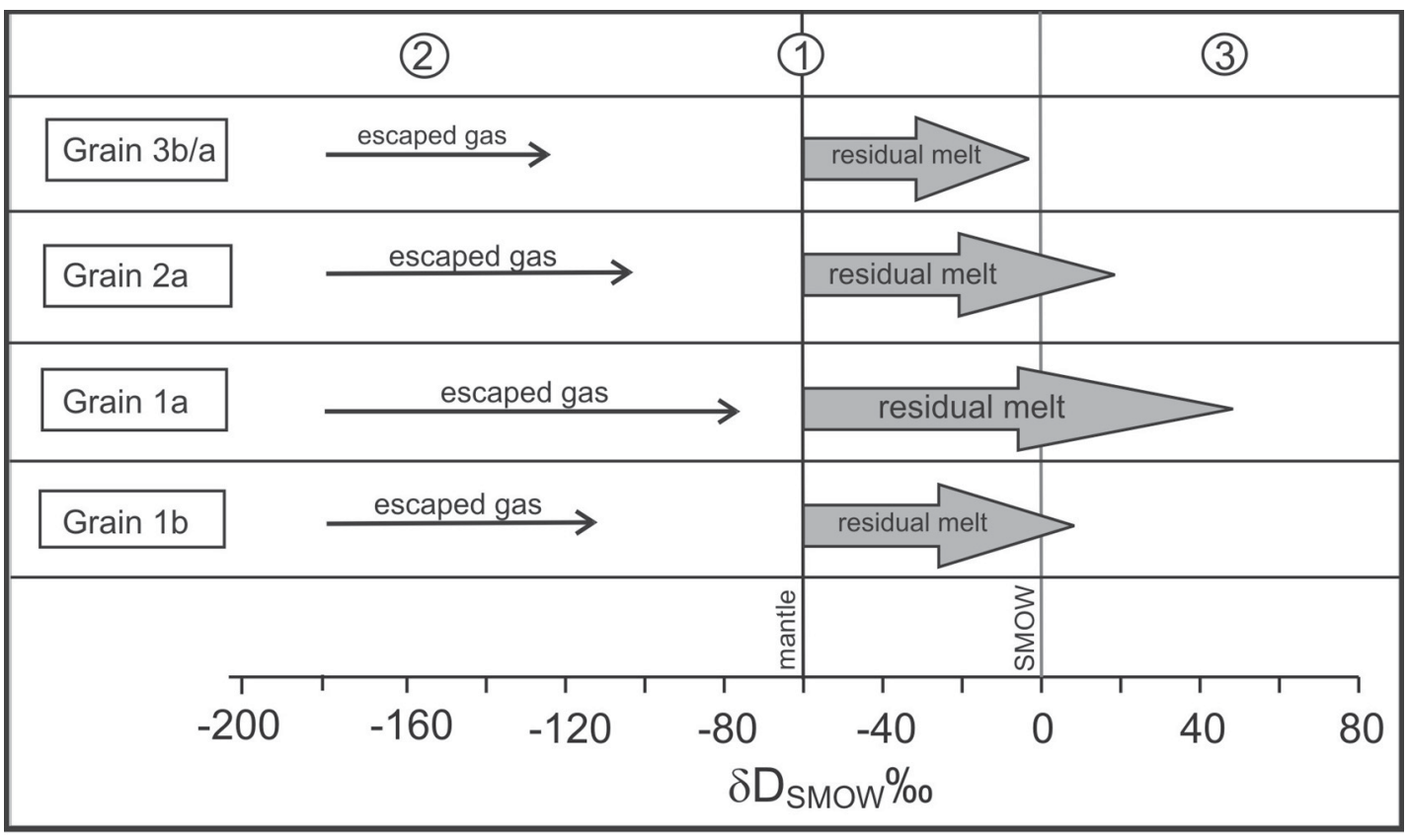

FIG. 8. Magmatic degassing model for the Boston Creek ferropicritic melt at $1000^{\circ} \mathrm{C}$. Partial melting in the mantle imparts a primary magmatic $\delta \mathrm{D}$ value of $-60 \%$ on the magma (1). Gases escaped from the melt as the reduced species $\mathrm{H}$ during magmatic emplacement (2). The gas/melt fractionation-factor for the $\mathrm{H}$ isotope is negative, and the escaped $\mathrm{H}$ gas is isotopically lighter, with lower $\delta \mathrm{D}$ values, whereas the residual $\mathrm{H}_{2} \mathrm{O}$ is heavier, with higher $\delta \mathrm{D}$ values. With progressive exsolution of volatiles, $\delta \mathrm{D}$ values for degassed melt shifted from the initial mantle-type value to progressively higher and, in some grains, a positive value (3).

The relationship envisaged between the $\mathrm{Cu}-\mathrm{PGM}-$ Ag mineralization and oxidation of the melt is represented in Figure 10. Laboratory experiments (Haughton et al. 1974) indicate that the $\mathrm{S}$ and $\mathrm{FeO}$ contents of basaltic melts in equilibrium with $\mathrm{Fe}-\mathrm{S}-\mathrm{O}$ liquids and varying $f\left(\mathrm{O}_{2}\right)$ and $f\left(\mathrm{~S}_{2}\right)$ show a strong positive correlation. Evidently, the $\mathrm{FeO}$ content of a basaltic melt exerts a strong influence on the solubility of sulfur and, therefore, PGE and related metals (Poulsen \& Ohmoto 1990, Fleet et al. 1991). The experiments also indicate a strong controlling role for temperature. Any significant reduction in $\mathrm{FeO}$ content and temperature markedly decreases the solubility of sulfur in the melt and promotes sulfide mineralization.

In this scenario, oxidation of the degassed residual melt in the interior of the Boston Creek ferropicrite led to $\mathrm{Fe}-\mathrm{Ti}$ oxide crystallization during formation of the gabbro layer. The resulting decrease in $\mathrm{FeO}$ content triggered sulfide supersaturation and the $\mathrm{Cu}-\mathrm{PGE}-\mathrm{Ag}$ mineralization. In addition, the dynamic or turbulent magmatic environment promoted by the degassing had the capacity to concentrate $\mathrm{Fe}-\mathrm{Ti}$ oxide and form sulfide highly enriched in PGE and Ag. Therefore, the high volatile and $\mathrm{FeO}$ contents and extensive degassing- related oxidation altogether are major controlling factors in the origin of magnetite-gabbro-hosted $\mathrm{Cu}-\mathrm{PGE}-\mathrm{Ag}$ sulfide mineralization.

\section{Depth of degassing}

Degassing of the Boston Creek ferropicritic magma could have occurred at depth in the mantle or at more shallow levels in the crust. The high $\delta \mathrm{D}$ values found for the Nushan xenoliths have been attributed to degassing processes in the mantle (Xia et al. 2002). The Boston Creek ferropicritic melt might possibly have degassed in the mantle. However, development of the extensive zones of vesiculation in the upper chilled margin (Crocket et al. 2005) and in the central gabbro layer renders degassing at crustal levels more plausible. The anomalously high $\delta \mathrm{D}$ values relative to ultramafic sills in the area (Stone et al. 2003) can be explained if the Boston Creek ferropicrite was emplaced at higher levels in the crust and contained higher volatile contents in the initial melt. Lower confining pressures during hypabyssal intrusion or volcanic flow favor enhanced degassing relative to the deeper-level intrusions. Higher contents of volatiles in the parental ferropicritic melt are 


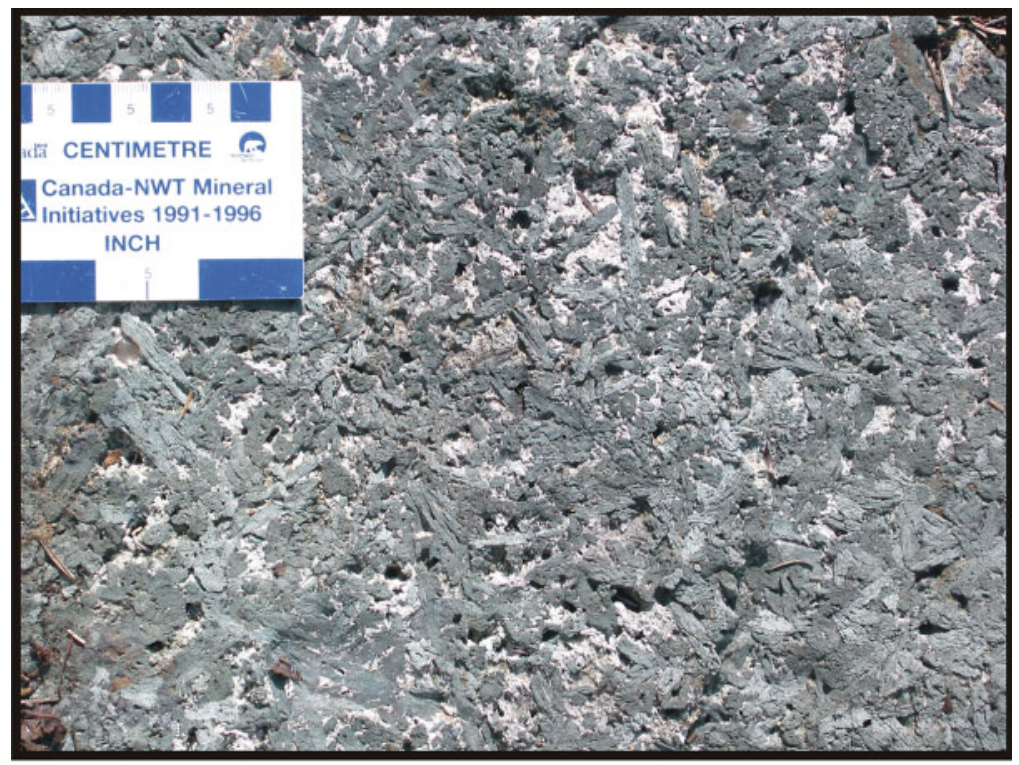

FIG. 9. Vesicular magnetite gabbro, host rock of magmatic $\mathrm{Cu}-\mathrm{PGE}-\mathrm{Ag}$ sulfide mineralization internally within the Boston Creek ferropicrite. Note the high abundance of vesicles, very coarse-grained clinopyroxene and fine-grained plagioclase (now albite). In thin sections, the vesicles are filled by calcite with or without pyrite.

consistent with the higher abundances of amphibole and vesicles, evidence for enhancement of clinopyroxene relative to plagioclase and orthopyroxene in the crystallization sequence (Stone et al. 1995a) and, perhaps, the anomalous thickness $(>30 \mathrm{~m})$ of the clinopyroxene spinifex layer. Indeed, high volatile contents appear to be characteristics of ferropicritic melts (e.g., Hanski 1992).

\section{CONCLUSIONS}

This study of the $\delta \mathrm{D}$ values and $\mathrm{H}_{2} \mathrm{O}$ and trace element contents of igneous amphibole from the Boston Creek ferropicrite, Archean Abitibi belt (Ontario), leads to the following conclusions:

1. The contrast with the uniform major-element and trace-element compositions and $\mathrm{H}_{2} \mathrm{O}$ content of the igneous amphibole, the negative $\delta \mathrm{D}$ values for wholerock samples, and the negative $\delta \mathrm{D}$ values for igneous amphiboles from similarly altered ultramafic sills in the area, indicates that the heterogeneous and high values of $\delta \mathrm{D}$ for the ferropicrite unit can best be attributed to magmatic processes.

2 . The anomalously high $\delta \mathrm{D}$ values, in conjunction with the development of extensive zones of vesiculation are explained by outgassing of hydrogen during emplacement of the ferropicritic melt at high levels in the crust.
3. Outgassing of hydrogen via dissociation of $\mathrm{H}_{2} \mathrm{O}$ resulted in oxidation and probably cooling of the degassed residual melt in the interior of the ferropicrite unit. The resulting crystallization of $\mathrm{Fe}-\mathrm{Ti}$ oxide reduced the $\mathrm{FeO}$ content of the melt and triggered $\mathrm{Cu}-\mathrm{PGE}-\mathrm{Ag}$ sulfide mineralization.

\section{ACKNOWLEDGEMENTS}

The study was conducted with grants from the Australian Research Council (Discovery Project DP0345971) and from the United States National Science Foundation (EAR-9405994 and EAR-9526877). The authors gratefully acknowledge Thomas Chacko and one anonymous reviewer for constructive comments, which significantly improved the final version of the manuscript. Robert F. Martin provided editorial assistance. We are also grateful to Ed Mathez, Kristine Larson, Chusi Li and Nick Arndt for constructive reviews of early drafts, and to Ed Ripley for kindly supplying the whole-rock hydrogen isotope analysis. The authors particularly thank Grant Henderson and Yuanming Pan for organizing the special session in honor of Mike Fleet, and for the invitation to take part. This paper is dedicated to Mike Fleet, who always encouraged innovative approaches in studies of geological problems. 


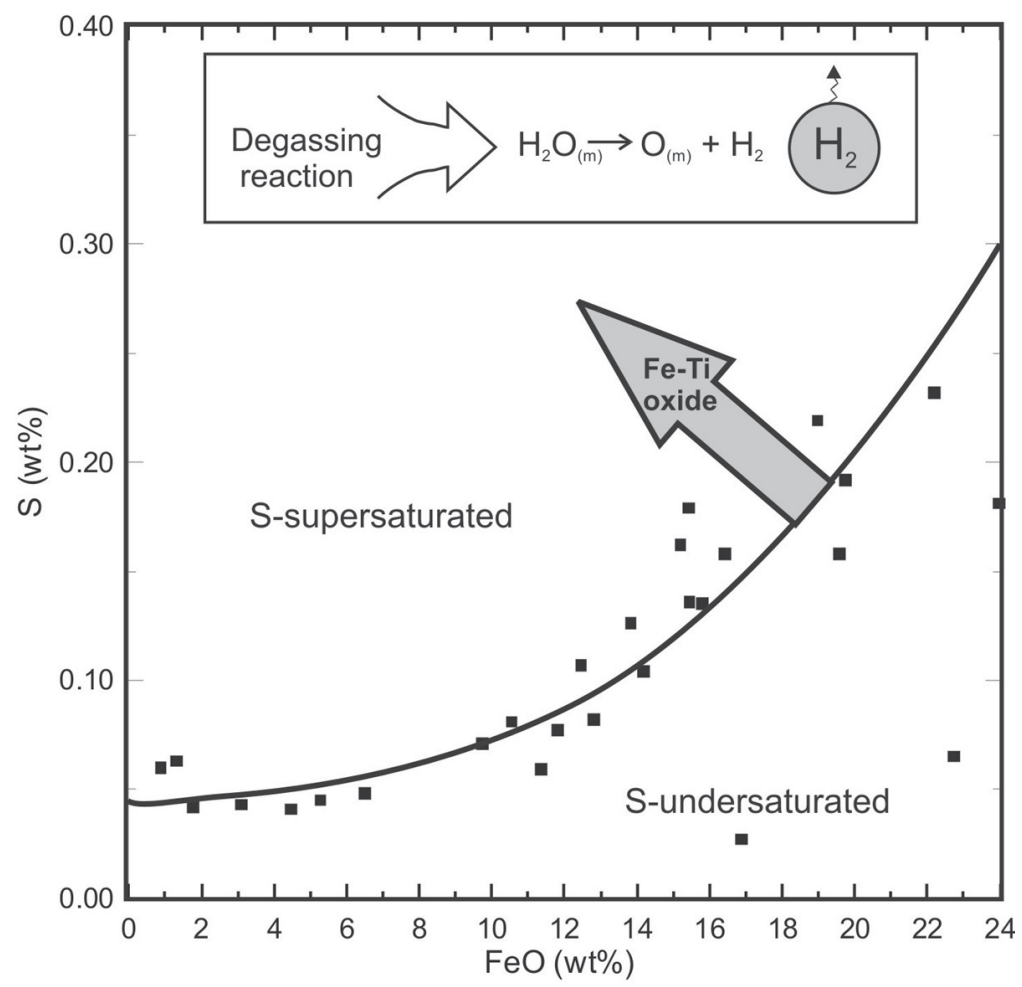

FIG. 10. The strong positive correlation of $\mathrm{S}$ and $\mathrm{FeO}$ contents of basaltic melts in equilibrium with $\mathrm{Fe}-\mathrm{S}-\mathrm{O}$ liquids at $1200^{\circ} \mathrm{C}$ and varying $f\left(\mathrm{O}_{2}\right)$ and $f\left(\mathrm{~S}_{2}\right)$ in laboratory experiments (Haughton et al. 1974). The black squares represent the experimental data of Haughton et al. (1974). In this model, Fe-Ti oxide crystallization markedly reduced the $\mathrm{FeO}$ content of the melt, which triggered S-supersaturation and $\mathrm{Cu}-\mathrm{PGE}-\mathrm{Ag}$ mineralization in magnetite gabbro internally within the Boston Creek ferropicrite.

\section{REFERENCES}

Ayer, J.F. \& TROwell, N. (2000): Geological compilation of the Kirkland Lake area, Abitibi Greenstone belt. Ontario Ministry of Northern Development and Mines, Misc. Release Data 58.

BERESFORD, S.W., CAS, R.A.F., LAMBERT, D.D. \& STONE, W.E. (2000): Vesicles in thick komatiite lava flows, Kambalda, Western Australia. J. Geol. Soc. London 157, 11-14.

Boettcher, A.L. \& O'Neil, J.R. (1980): Stable isotope, chemical and petrographic studies of high pressure amphiboles and micas: evidence for metasomatism in the mantle source regions of alkali basalts and kimberlites. Am. J. Sci. 280A, 594-621.

Christie, D.M., Carmichael, I.S.E. \& Langmuir, C.H. (1986): Oxidation states of mid-ocean ridge basalt glasses. Earth Planet. Sci. Lett. 79, 397-411.
Crocket, J.H., Leng, D.M., Good, D.J., Stone, W.E. \& Stone, M.S. (2005): The spinifex layer of the Boston Creek ferropicrite, Abitibi Belt, Ontario: mineralogical and geochemical evidence for an unusual history of clinopyroxene growth and magma recharge. Can. Mineral. 43, 1759-1780.

Deloule, E., Albarède, F. \& Sheppard, S.M.F. (1991a): Hydrogen isotope heterogeneities in the mantle from ion probe analysis of amphiboles from ultramafic rocks. Earth Planet. Sci. Lett. 105, 543-553.

, France-Lanord, C. \& Albarède, F. (1991b): $\mathrm{D} / \mathrm{H}$ analysis of minerals by ion probe. In Stable Isotope Geochemistry: a tribute to Samuel Epstein (H.P. Taylor, Jr., J.R. O'Neil \& I.R. Kaplan, eds.). Geochem. Soc., Spec. Publ. 3, 53-62.

Paillat, O., Pichavant, M. \& Scaillet, B. (1995): Ion microprobe determination of water in silicate glasses: methods and applications. Chem. Geol. 125, 19-28. 
Fleet, M.E., Stone, W.E. \& CRocket, J.H. (1991): Partitioning of palladium, iridium and platinum between sulfide liquid and basaltic melt: effects of melt composition, concentration and oxygen fugacity. Geochim. Cosmochim. Acta 55, 2545-2554.

Garcia, M.O., Muenow, D.W., Aggrey, S.E. \& O’Neil, J.R. (1989): Major elements, volatile and stable isotope geochemistry of Hawaiian submarine tholeiitic glasses. $J$. Geophys. Res. 94, 10525-10538.

Grove, T.L. \& PARMAN, S.W. (2004): Thermal evolution of the Earth as recorded by komatiites. Earth Planet. Sci. Lett. 219, 173-187.

Gurenko, A.A. \& Chaussidon, M. (1995): Enriched and depleted primitive melts included in olivine from Icelandic tholeiites: origin by continuous melting of a single mantle column. Geochim. Cosmochim. Acta 59, 2905-2917.

HANSKI, E. (1992): Petrology of the Pechenga ferropicrites and cogenetic Ni-bearing gabbro-wehrlite intrusions, Kola Peninsula, Russia. Geol. Surv. Finland, Bull. 367.

Haughton, D.R., Roeder, P.L. \& Skinner, B.J. (1974): Solubility of sulfur in mafic magmas. Econ. Geol. 69, 451-467.

InOUe, T., RAPP, R.P., Zhang, J., GASPARIK, T., WEIDNER, D.J. \& IRIFUNE, T. (2000): Garnet fractionation in a hydrous magma ocean and the origin of Al-depleted komatiites: melting experiments of hydrous pyrolite with REEs at high pressure. Earth Planet. Sci. Lett. 177, 81-87.

Larson, M.S., Stone, W.E., Morris, W.A. \& Crocket, J.H. (1998): Magnetic signature of magnetite-enriched rocks hosting platinum-group element mineralization within the Archean Boston Creek Flow. Geophysics 63, 440-445.

LEAKE, B.E. and 21 others (1997): Nomenclature of amphiboles: report of the Subcommittee on Amphiboles of the International Mineralogical Association, Commission on New Minerals and Mineral Names. Can. Mineral. 35, 219-246.

Litasov, K., OHTANi, E. \& TANIGUCHI, H. (2001): Melting relations of hydrous pyrolite in $\mathrm{CaO}-\mathrm{MgO}-\mathrm{Al}_{2} \mathrm{O}_{3}-\mathrm{SiO}_{2}-\mathrm{H}_{2} \mathrm{O}$ system at the transition zone pressures. Geophys. Res. Lett. 28, 1303-1306.

MAtheZ, E.A. (1984): Influence of degassing on oxidation states of basaltic magmas. Nature 310, 371-375.

McCuaig, T.C. \& Kerrich, R. (1998): P-T-t deformationfluid characteristics of lode gold deposits: evidence from alteration systematics. Ore Geol. Rev. 12, 381-453.

McDonough, W.F. \& Frey, F.A. (1989): Rare earth elements in upper mantle rocks. In Geochemistry and Mineralogy of Rare Earth Elements (B.R. Lipin \& G.A. McKay, eds.). Rev. Mineral. 21, 99-145.

Parman, S.W., Dann, J.C., Grove, T.L. \& DE Wit, M.J. (1997): Emplacement conditions of komatiite magmas from the 3.49 Ga Komati Formation, Barberton Greenstone Belt, South Africa. Earth Planet. Sci. Lett. 150, 303-323.

Grove, T.L. \& DANN, J.C. (2001): The production of Barberton komatiites in an Archean subduction zone. Geophys. Res. Lett. 28, 2513-2516.

Pineau, F., Shilobreeva, S., KadiK, A. \& Javoy, M. (1998): Water solubility and $\mathrm{D} / \mathrm{H}$ fractionation in the system basaltic andesite- $\mathrm{H}_{2} \mathrm{O}$ at $1250^{\circ} \mathrm{C}$ and between 0.5 and 3.0 kbars. Chem. Geol. 147, 173-184.

Poulson, S.R. \& Онмото, H. (1990): An evaluation of the solubility of sulfide sulfur in silicate melts from experimental data and natural samples. Chem. Geol. 85, 57-75.

Rock, N.M.S. \& LEAKE, B.E. (1984): The International Mineralogical Association amphibole nomenclature scheme: computerization and its consequences. Mineral. Mag. 48, 211-227.

SATO, M. \& WRIGHT, T.L. (1966): Oxygen fugacity directly measured in volcanic glasses. Science 153, 1103-1105.

SEMET, M.P. \& ERNST, W.G. (1981): Experimental stability relations of the hornblende magnesio-hastingsite. Geol. Soc. Am., Bull. 92, 71-74.

Sheppard, S.M.F. \& Epstein, S. (1970): D/H and ${ }^{18} \mathrm{O} /{ }^{16} \mathrm{O}$ ratios of minerals of possible mantle or lower crustal origin. Earth Planet. Sci. Lett. 9, 232-239.

Spear, F.S. (1981): An experimental study of hornblende stability and compositional variability in amphibolite. Am. J. Sci. 281, 697-734.

STONE, W.E. (1985): Geochemistry of the Boston Flow Fe-Rich Komatiite, Kirkland Lake Area, Northeastern Ontario. M.Sc. thesis, Univ. Western Ontario, London, Ontario.

\& CRocket, J.H. (2003): Platinum-group element contents of chromites from mafic-ultramafic layered flows, Abitibi greenstone belt, Ontario: implications for geochemical fractionation and mineral exploration. Mineral. Petrol. 78, 139-147.

Dickin, A.P. \& FleEt, M.E. (1995a): Origin of Archean ferropicrites: geochemical constraints from the Boston Creek Flow, Abitibi greenstone belt, Ontario, Canada. Chem. Geol. 121, 51-71.

\& FleET, M.E. (1993): Sulfide-poor platinum-group mineralization in komatiitic systems: Boston Creek flow, layered basaltic komatiite, Abitibi Belt, Ontario. Econ. Geol. 88, 817-836.

$\&$

(1995b): Differentiation processes in an unusual iron-rich alumina-poor Archean ultramafic/mafic igneous body, Ontario. Contrib. Mineral. Petrol. 119, 287- 300.

\& LARSON, M.S. (1996): PGE

mineralization in Archean volcanic systems: geochemical 
evidence from thick, differentiated mafic-ultramafic flows, Abitibi greenstone belt, Ontario, and implications for exploration. J. Geochem. Explor. 56, 237-263.

Deloule, E., Larson, M.S. \& Lesher, C.M. (1997): Evidence for hydrous high-MgO melts in the Precambrian. Geology 25, 143-146.

\& STONE, M.S. (2003): Hydromagmatic amphibole in komatiitic, tholeiitic and ferropicritic units, Abitibi greenstone belt, Ontario and Québec: evidence for Archaean wet ultrabasic melts. Mineral. Petrol. 77, 39-65.

Fleet, M.E., Crocket, J.H. \& Kingston, D.M. (1992): Platinum-group minerals in pyroxenite from the Boston Creek Flow basaltic komatiite, Abitibi greenstone belt, Ontario. Can. Mineral. 30, 109-119.

, Jensen, L.S. \& Church, W.R. (1987): Petrography and geochemistry of an unusual Fe-rich basaltic komatiite from Boston Township, northeastern Ontario. Can. J. Earth Sci. 24, 2537-2550.

Sun, S.-S. \& McDonough, W.F. (1989): Chemical and isotopic systematics of oceanic basalts: implications for mantle composition and processes. In Magmatism in Ocean Basins (A.D. Saunders \& M.J. Norry, eds.). Geol. Soc., Spec. Publ. 42, 313-345.

TAYLOR, B.E. (1986): Magmatic volatiles: isotopic variation of $\mathrm{C}, \mathrm{H}$, and S. In Stable Isotopes in High Temperature Geological Processes (J.W. Valley, H.P. Taylor Jr. \& J.R. O'Neil, eds.). Rev. Mineral. 16, 185-225.

TAYLOR, H.P. (1974): The application of oxygen and hydrogen isotope studies to problems of hydrothermal alteration and ore deposition. Econ. Geol. 69, 843-883.
(1986): Igneous rocks. II. Isotopic case studies of circumpacific magmatism. In Stable Isotopes in High Temperature Geological Processes (J.W. Valley, H.P. Taylor Jr. \& J.R. O’Neil, eds.). Rev. Mineral. 16, 273-317.

Valley, J.W., Graham, C.M., Harte, B., Eiler, J.M. \& KINNY, P.D. (1998): Ion microprobe analysis of oxygen, carbon and hydrogen isotope ratios. In Applications of Microanalytical Techniques to Understanding Mineralizing Processes (M.A. McKibben, W.C. Shanks III \& W.I. Ridley, eds.). Rev. Econ. Geol. 7, 73-98.

Wagner, C., Deloule, E. \& Mokhtari, A. (1996): Richteritebearing peridotites and MARID-type inclusions in lavas from northeastern Morocco: mineralogy and $\mathrm{D} / \mathrm{H}$ isotopic studies. Contrib. Mineral. Petrol. 124, 406-421.

WALKer, R.J. \& Stone, W.E. (2001): Os isotope constraints on the origin of the $2.7 \mathrm{Ga}$ Boston Creek flow, Ontario, Canada. Chem. Geol. 175, 567-579.

WiLSON, A.H. (2003): A new class of silica enriched, highly depleted komatiites in the southern Kaapvaal Craton, South Africa. Precamb. Res. 127, 125-141.

XiA, Q.-K., Deloule, E., Wu, Y.-B., Chen, D.-G. \& Cheng, H. (2002): Anomalously high $\delta \mathrm{D}$ values in the mantle. Geophys. Res. Lett. 29, DOI 10.1029/2001GL013887.

Received August 31, 2004, revised manuscript accepted October 6, 2005. 